sideration in the literature [13]. As a result, the findings obtained in this investigation may be applicable to the study of PMA in other cell systems. According to Augustinsson [5], each esterase type exists in multiple forms and each animal species has its own typical spectrum of esterases in plasma and tissues [14]. In the presence of marked variations in location, form and activity, one might expect significant differences in the effects of drugs which stimulate or inhibit these enzymes in different species. If the pharmacological action of a drug is dependent on ester groups, then the presence of esterases in all affected cells and tissues would have to be considered in evaluating the influence of the agent. PMA has been used extensively as a co-carcinogen in animal studies [13]. It would be of interest to determine if endogenous esterases or the concomitant use of esterase inhibitors would influence the tumor-promoting action of PMA.

Department of Pediatrics, University of Minnesota, Gundu H. R. RaO School of Medicine, Minneapolis, Minn. 55455, U.S.A.

\section{REFERENCES}

1. M. B. Zucker, W. Troll and S. Belman, J. Cell Biol. 60, 325 (1974).

2. R. D. Estensen and J. G. White, Am. J. Path. 74, 441 (1974).

3. J. G. White and R. D. Estensen, Am. J. Path. 74, 455 (1974).

4. J. G. White, G. H. R, Rao and R. D. Estensen, Am. J. Path. 75, 45 (1974).

5. K. B. Augustinsson, Ann. N.Y. Acad. Sci. 94, 844 (1961).

6. W. Kalow and R. O. Davies, Biochem. Pharmac. 1, 183 (1958).

7. J. G. White, Blood 31, 604 (1971).

8. C. C. Clawson and J. G. White, Am. J. Path. 65, 367 (1971).

9. P. N. Walsh, Br. J. Haemat. 22, 205 (1972).

10. J. G. White, Am. J. Path. 69, 439 (1972).

11. G. H. R. Rao, A. A. Jachimowicz and J. G. White, J. Chromat. in press.

12. Z. Jersushalmy and M. B. Zucker, Thromb. Diath. haemorrh. 15, 413 (1966).

13. F. Hecker, Naturwissenschaften 54, 282 (1967).

14. B. N. La Du and H. Snady, in Concepts in Biochemical Pharmacology(Eds. B. B. Brodie and J. R. Gillette) Part II, p. 778. Springer, Berlin (1971).

\title{
Drug and fatty acid hydroxylation by solubilized human liver microsomal cytochrome $\mathbf{P}-\mathbf{4 5 0}$-Phospholipid requirement*
}

\author{
(Received 15 March 1974; accepted 7 June 1974)
}

\begin{abstract}
The enzyme system in rabbit liver microsomes which catalyzes the hydroxylation of a variety of fatty acids, hydrocarbons, drugs and other foreign compounds was solubilized by Lu and Coon $[1,2]$, and resolved into three components: cytochrome P-450, NADPH-cytochrome P-450 reductase, and a heat-stable substance called Factor B [3]. The heatstable component was identified as phosphatidylcholine and was shown to be essential for the reductase-catalyzed transfer of electrons from NADPH to cytochrome P-450 [4]. Synthetically prepared compounds such as lauroylglyceryl-3-phosphorylcholine (lauroyl-GPC) were found to be active when substituted for the microsomal phosphatidylcholine fraction. Subsequently, the corresponding enzyme systems in rat [5,6] and mouse [7] liver microsomes as well as in a yeast, Candida tropicalis $[8,9]$, were reconstituted by similar procedures. The cytochrome P-448-containing enzyme system, which oxidizes polycyclic aromatic carcinogens, was also reconstituted and was found to
\end{abstract}

* This work was supported by the National Science Foundation (Grant GB-30419X) and the United States Public Health Service (Grant AM-10339). A preliminary report of this investigation has been presented (Fifth International Congress on Pharmacology, San Francisco, Calif., 1972). require the reductase and phosphatidylcholine for activity, as shown with 3-methylcholanthrene-treated rats [10] and $\beta$-naphthoflavone-treated mice of both inducible and noninducible strains [?].

The present paper describes the solubilization of human liver microsomal cytochrome P-450 and its reconstitution into a functional hydroxylating system by the addition of the reductase and phosphatidylcholine. The presence of cytochrome P-450 in human liver microsomes was first reported by Alvares et al. [11], and the hydroxylation of various substrates has been shown to occur in the microsomal fraction obtained from human liver biopsy samples $[12,13]$, fetal liver [14], and postmortem liver from patients with abnormal medical histories [15] or apparcntly normal individuals who met sudden deaths [16].

A liver sample from a 21-year-old male who had met an accidental death about $4 \mathrm{hr}$ previously was cut into pieces, washed with $0.25 \mathrm{M}$ sucrose and frozen. All procedures were carried out at $4^{\circ}$ unless stated otherwise. The microsomal fraction was isolated according to Nelson et al. [16], except that $0.5 \mathrm{mM}$ dithiothreitol was added to all solutions, and was stored at $-20^{\circ}$ under nitrogen. The yield of microsomal protein was $13 \mathrm{mg} / \mathrm{g}$ of liver, wet wt. Cytochrome P-450 and P-420 werc present in the amounts of 0.25 and $0.42 \mathrm{nmolc} /$ 


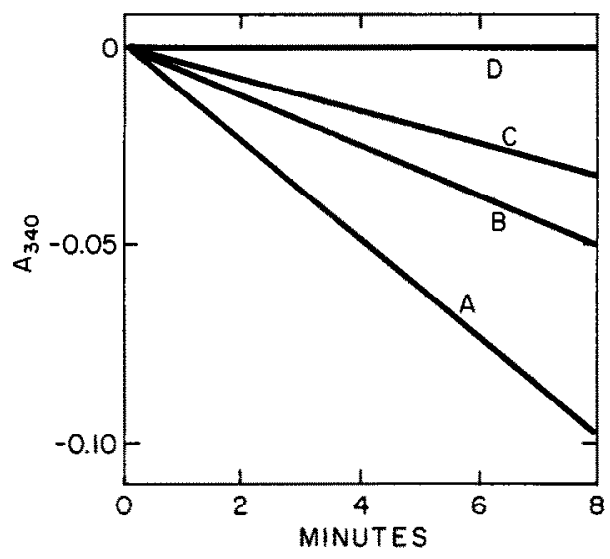

Fig. 1. The complete reaction mixture contained the human liver cytochrome $P-450$ fraction $(0.62$ nmole; $1.3 \mathrm{mg}$ protein), rat liver NADPH-cytochrome $P-450$ reductase fraction [3] (0.03 $\mathrm{mg}$ protein), lauroyl-GPC (0.05 mg), $d$-benzphetamine $(1.0 \mu \mathrm{molc})$, potassium phosphate buffer, $\mathrm{pH} 7.7$ $(100 \mu$ moles $)$ and NADPH $(0 \cdot 1 \mu$ mole $)$ as the last addition in a final volume of $1.0 \mathrm{ml}$. Curve $A$, complete system; curve $B$, benzphetamine omitted; curve $C$, phosphatidylcholine omitted; and curve D, cytochrome P-450 fraction omitted. The temperature was $30^{\circ}$.

mg of protein respectively. Microsomes were thawed, solubilized with cholate, and fractionated with ammonium sulfate by a modification of procedures used previously with rat liver microsomes [17]. The preparation was centrifuged at $100,000 \mathrm{~g}$ for $1 \mathrm{hr}$ to remove turbidity, and the extract was treated with solid ammonium sulfate. The precipitate formed at $35 \%$ salt saturation was removed by centrifugation and discarded, and the supernatant fraction was brought to 45 per cent saturation with ammonium sulfate. The floating precipitate, which separated on centrifugation, was dissolved in $30 \mathrm{ml}$ of $0.1 \mathrm{M}$ Tris-chloride buffer, $\mathrm{pH} 7 \cdot 4$, containing $20 \%$ glycerol and $0.5 \mathrm{mM}$ dithiothreitol, and the solution was then brought to 45 per cent saturation with ammonium sulfate. The resulting floating precipitate was taken up in $5 \mathrm{ml}$ of the same buffer mixture and centrifuged for 1 hr at $100,000 \mathrm{~g}$. The supernatant fraction was used as the source of cytochrome P-450 in the experiments to be described. This procedure was devised to obtain purification rather than high yield.

Cytochrome P-450 and cytochrome P-420 were estimated according to Omura and Sato [18], except that both cuvettes were bubbled with $\mathrm{CO}$ and dithionite was added to one, thereby preventing interference by any hemoglobin contaminating the samples. Protein concentrations were determined according to Lowry et al. [19]. Lauroyl-GPC, a 5:1 mixture of the di-and mono-lauroyl compounds, was a gift from Dr. W. E. M. Lands.

The cytochrome P-450 content of the human liver microsomes, as shown in Table 1, was in the range reported by others for comparable liver samples [16]. The extraction procedure caused a slight decrease in the cytochrome $\mathrm{P}-450$ content, but fractionation with ammonium sulfate yielded a preparation in which the cylochrome P-450 was purified about 2-fold with respect to the microsomes and the cytochrome P-420 was largely removed.

The ability of the solubilized cytochrome P-450 to catalyze benzphetamine $N$-demethylation was determined by a spectrophotometric assay in which substrate-dependent NADPH disappearance was determined at $340 \mathrm{~nm}[5,6]$. The results presented in Fig. 1 indicate that drug hydroxylation was linear with time for at least $8 \mathrm{~min}$, and that the reaction was completely dependent on the presence of the cytochrome P-450 fraction. Upon the omission of either benzphetamine or phospholipid, the rate of NADPH oxidation was reduced. The rate in the absence of benzphetamine apparently represents electron flow from NADPH to oxygen via the reductase and cytochrome $P-450$ due to the autoxidizability of the latter, as has previously been observed with the rat and rabbit liver reconstituted microsomal enzyme systems [6]. In the absence of lauroyl-GPC, the rate was reduced to less than that with substrate omitted; it is evident, therefore, that cytochrome P-450 from human liver, like that from the liver of several animal species studied, requires phospholipid for catalytic activity. The rate of benzphetamine demethylation, estimated in such experiments as $1.5 \mathrm{nmoles} / \mathrm{min} / \mathrm{nmole}$ of cytochrome P-450, was also determined by direct measurement of formaldehyde formation by the method of Nash [20], as modified by Cochin and Axelrod [21] with similar results. In other experiments, aminopyrine and hexane appeared to be hydroxylated by the reconstituted enzyme system, as judged by the spectrophotometric assay, but the results were not confirmed by direct determination of products formed.

Evidence was obtained that the reconstituted enzyme system also hydroxylates laurate, as shown in Table 2. LauroylGPC appeared to be about as effective as microsomal lipid fraction (Fraction B) in supporting this reaction, whereas upon omission of phospholipid the rate of hydroxylation dropped to about one-fifth the value. Fatty acid hydroxylation in human liver microsomal suspensions has also been described by Yaffe et al. [14].

The results presented indicate that human liver cytochrome P.450 can be solubilized from microsomal membranes by procedures previously applied successfully to liver microsomes of other species and may be partially purified

Table 1. Content of cytochrome P-450 and cytochrome P-420 in preparations*

\begin{tabular}{lcc}
\hline \multicolumn{1}{c}{ Preparation } & $\begin{array}{c}\text { Cytochrome P-450 } \\
\text { (nmoles/mg protein) }\end{array}$ & $\begin{array}{c}\text { Cytochrome P-420 } \\
\text { (nmoles/mg protein) }\end{array}$ \\
\hline $\begin{array}{l}\text { Microsomal } \\
\text { suspension }\end{array}$ & 0.25 & 0.42 \\
$\begin{array}{l}\text { Cholate extract } \\
\text { Ammonium sulfate } \\
\text { precipitate } \\
(0-45 \% \text { saturation) }\end{array}$ & $0 \cdot 17(0 \cdot 14-0.21)$ & $0.41(0.34-0.52)$ \\
\hline
\end{tabular}

* The values given are an average, and the numbers in parentheses indicate the range obtained with the cholate extract (four experiments) and the ammonium sulfate fraction (five experiments). 
Table 2. Fatty acid hydroxylation by reconstituted enzyme system containing human liver cytochrome $\mathbf{P}-450^{*}$

\begin{tabular}{|c|c|c|}
\hline Phospholipid added & $\begin{array}{c}\text { No. of } \\
\text { experiments }\end{array}$ & $\begin{array}{l}\text { Laurate hydroxylated } \\
\text { (nmoles/min/nmole } \\
\text { cytochrome } \mathrm{P}-450 \text { ) }\end{array}$ \\
\hline \multicolumn{3}{|l|}{ Microsomal phospholipid } \\
\hline Lauroyl-GPC (0.05 mg) & 5 & $0.27(0.21-0.32)$ \\
\hline None & 7 & $0.06(0.01-0.12)$ \\
\hline
\end{tabular}

* The reaction mixture was similar to that in Fig. 1 , except that the substrate was $1-{ }^{14} \mathrm{C}$-laurate $(0 \cdot 25 \mathrm{mM}$, final concentration) and the incubation time was $15 \mathrm{~min}$. The radioactive hydroxylaurate formed was isolated by silicic acid chromatography [22]. The values given are an average of several experiments, and the numbers in parentheses indicate the range.

and freed of contaminating cytochrome $\mathrm{P}-420$ by fractionation with ammonium sulfate. The resulting enzyme preparation catalyzes the hydroxylation of benzphetamine and laurate, but exhibils maximal aclivity in such reactions only when supplemented with phosphatidylcholine. Stopped flow measurements have shown that, in the reconstituted system from rat liver microsomes, electron transfer from NADPH to cytochrome P-450 occurs at a rate sufficiently rapid to support substrate hydroxylation only when phosphatidylcholine is present $\lceil 4\rceil$. In addition, evidence has been obtained that the phospholipid may form a dissociable complex with cytochrome P-450 and the NADPH-cytochrome $P-450$ reductase, but that large aggregates or membrane-like structures are not produced, as judged by such techniques as sedimentation, gel exclusion chromatography and electron microscopy [17]. On the other hand, the manner in which the phospholipid acts is not yet understood at a detailed mechanistic level.

It should be noted that human liver microsomes are lower in cytochrome P.450 content than are microsomes from commonly used laboratory animals. Furthermore, the solubilized human liver microsomal cytochrome P-450 appears to be more labile than that from rat or rabbit and is more difficult to purify because of the presence of large amounts of lipid. Accordingly, despite the obvious importance of elucidating the manner in which the human liver enzyme sys. tem metabilizes drugs and a varicty of other foreign compounds, it appears that more rapid progress may be made by first isolating and characterizing the individual components from other species in which liver is a richer source of this enzyme system [23]. The present study indicates that, despite some particular difficulties in working with the system from human liver, the cytochrome P-450 may be solubilized by a detergent in the presence of glycerol as a stabilizing agent and that the presence of phospholipid is necessary for activity. Whether an electron acceptor other than the iron atom is present in the human liver cytochrome P-450 preparation, as was recently shown for the partially purified rabbit liver cytochrome P.450 [24], remains to be established.

Department of Biological Chemistry, Medical School,

ROBERT M. KASCHNIT7* The University of Michigan, Ann Arbor, Mich. 48104, U.S.A. MiNOR J. COON

* Present address: Scripps Clinic and Research Foundation, Department of Biochemistry, La Jolla, Calif. 92037. U.S.A.

\section{REFERENCES}

1. A. Y. H. Lu and M. J. Coon, J. hiol. Chem. 243, 1331 (1968).

2. M. J. Coon and A. Y. H. Lu, in Microsomes and Drug Oxidations (Ed. J. R. Gillette), p. 151. Academic Press, New York (1969).

3. A. Y. H. Lu, K. W. Junk and M. J. Coon, J. biol. Chem. 244, 3714 (1969).

4. H. W. Strobel, A. Y. H. Lu, J. Heidema and M. J. Coon, J. biol. Chem. 245, 4851 (1970).

5. A. Y. H. Lu, H. W. Strobel and M. J. Coon, Biochem. biophys. Res. Commun. 36, 545 (1969).

6. A. Y. H. Lu, H. W. Strobel and M. J. Coon, Molec. Pharmac. 6, 213 (1970).

7. D. W. Nebert, J. K. Heidema, H. W. Strobel and M. J. Coon, J. biol. Chem. 248, 7631 (1973).

8. J. M. Lebeault, E. T. Lode and M. J. Coon, Biochem. biophys. Res. Commun. 42, 413 (1971).

9. W. Duppel, J. M. Lebeault and M. J. Coon, Eur. J. Biochem. 36, 583 (1973).

10. A. Y. H. Lu, R. Kuntzman, S. West, M. Jacobson and A. H. Conney, J. biol. Chem. 247, 1727 (1972).

11. A. P. Alvares, G. Schilling, W. Levin, R. Kuntzman, L. Brand and L. C. Mark, Clin. Pharmac. Ther. 10, 655 (1969).

12. R. Kuntzman, L. C. Mark, L. Brand, M. Jacobson, W. Levin and A. H. Conney, J. Pharmac. exp. Ther. 152, 151 (1966).

13. B. Schoene, R. A. Fleischmann, H. Remmer and H. F. Oldershausen, Eur. J. clin. Pharmac. 4, 65 (1972).

14. S. J. Yaffe, A. Rane, F. Sjöqvist, L.-O. Boréus and S. Orrenius, Life Sci. 9, 1189 (1970).

15. F. J. Darby, W. Newnes and D. A. Price Evans, Biochem. Pharmac. 19, 1514 (1970).

16. E. B. Nelson, P. P. Raj, K. J. Belfi and B. S. S. Masters, J. Pharmac, exp. Ther. 178, 580 (1971).

17. A. P. Autor, R. M. Kaschnitz, J. K. Heidema and M. J. Coon, Molec. Pharmac. 9, 93 (1973).

18. T. Omura and R. Sato, J. biol. Chem. 239, 2370 (1964).

19. O. H. Lowry, N. J. Rosebrough, A. L. Farr and R. J. Randall, J. biol. Chem. 193, 265 (1951).

20. T. Nash, Biochem. J. 55, 416 (1953).

21. J. Cochin and J. Axelrod, J. Pharmac. exp. Ther. 125 , 105 (1959).

22. M. Kusunose, E. Kusunose and M. J. Coon, J. biol. Chem. 239, 1374 (1969).

23. M. J. Coon, T. A. van der Hoeven, R. M. Kaschnitz and H. W. Strobel, Ann. N.Y. Acad. Sci. 212, 449 (1973).

24. D. P. Ballou, C. Veeger, T. A. van der Hoeven and $M$. I. COOI. FEBS Le'II. 38, 337 (1974). 